\title{
THEORETICAL AND PRACTICAL ASPECTS REGARDING THE INTERACTION BETWEEN HUMAN WORKERS AND ROBOTS AT WORK*
}

\author{
Dan TुOP**
}

\begin{abstract}
Faced as we are by an unpredictable world of work, we have a greater need than ever for empirical studies on new and imaginative ways of organizing, rewarding, and managing work - matched with scientific knowledge about causality and complexity. Economic reality denotes that society is in a "digital revolution" and more and more activities previously carried out directly by human force are now being replaced by various computer programs, or by automating technical processes. It is expected that by 2030 many jobs will be filled by robots or devices, people will be replaced, but new types of jobs will be created. Among the jobs that will disappear in the next 25 years are accountants, agricultural workers and even construction workers. Soon, humans will compete with robots in the job market. The job market is changing radically in the next decade. Robots are increasingly present in our lives and we must prepare for the time when they will take over some of our jobs.
\end{abstract}

Keywords: digital revolution; job market; robots

DOI: 53373 / REDS.2021.53.4.035

ORCID 0000-0002-1695-9967

Faced as we are by an unpredictable world of work, we have a greater need than ever for empirical studies

Technologies in partnership with the Institute for the Future (IFTF) in California, $85 \%$ of the trades that will exist in 2030 have not yet been invented and over $10 \%$ of jobs current jobs will be automated in the next decade.

According to the Guide to the trades of the future - the labor market opportunities in the world of tomorrow ${ }^{1}$ made in September 2018 by the INACO Association, Robots threaten several professions, they have replaced man in the world.

Professions such as ,,virtual and augmented reality creator" or ,,robotic avatar designer" now seem to be in the field of SF. Such professions will take the place of classic jobs in the next 10 years, and people will have nothing to do but adapt to the demands of the labor market.

Economic reality denotes that society is in a "digital revolution" and more and more activities previously carried out directly by human force are now being replaced by various computer programs, or by automating technical processes.

* This article is a communication presented at 19th ILERA World Congress, Lund, June 23, 2021.

** Professor PhD, President of the Association for the Study of Labor Relations - Romania.

${ }^{1}$ https://inaco.ro/wp-content/uploads/2018/09/Ghidul-meseriilor-viitorului-6-sep-2018.pdf (pg.13) 
Soon, humans will compete with robots in the job market. According to experts, in 60 years artificial intelligence will be a serious threat to humanity on new and imaginative ways of organizing, rewarding, and managing work - matched with scientific knowledge about causality and complexity.

In a study published by Stanford University in $2016^{2}$, it is expected that by 2030 many jobs will be filled by robots or devices, people will be replaced, but new types of jobs will be created. Among the jobs that will disappear in the next 25 years are accountants, agricultural workers and even construction workers. However, cybersecurity analysts, robotic avatar designers, biomedical engineers and geneticists will be in high demand. The employers' argument is that robots are more productive than humans, do not want to leave and do not resign.

According to a study conducted in 2017 by Dell. By 2022, the similarity between robot and man, the thought processes will be equal to about $10 \%$, until 2040 - $50 \%$, and in 2075 the thinking of robots will not be able to be differentiated from those of a $\operatorname{man}^{3}$.

The US and China are competing to take advantage of artificial intelligence, and the European Union does not want to be left behind. Thus, in February 2020, it presented a new approach to the digital economy of the EU bloc with a new "strategy for shaping Europe's digital future". Behind this vague description, the objectives of the new strategy are specific: Essentially European - regulation that "puts people first" and encourages "reliable technology."

According to a study conducted in $2017^{4}$ by Dell Technologies in partnership with the Institute for the Future (IFTF) in California, "85\% of the trades that will exist in 2030 have not yet been invented" and "over $10 \%$ of jobs current jobs will be automated in the next decade."

According to the Guide to the trades of the future - labor market opportunities in tomorrow's world, made in September 2018 by the INACO Association, "Robots threaten even the legal profession. In law, there are software programs offered by Kira Systems - Machine Learning Contract Search, Review and Analysis with solutions that reduce documentation time by $60 \%$, including scanning documents and identifying the most relevant arguments. Robots have replaced man in the world."

The exponential development of technologies ${ }^{6}$ based on artificial intelligence will make what happened to Kodak happen to a lot of other industries in the coming years, that is, a wave of bankruptcies.

${ }^{2}$ One Hundred Year Study on Artificial Intelligence, https://ai100.stanford.edu/, accessed on 22.08.2020

3 Etzioni Oren, No, the Experts Don't Think Superintelligent $A l$ is a Threat to Humanity. URL: https://www.technologyreview.com/s/602410/no-the-experts-dont-think-superintelligent-aiis-a-

threat-to-humanity, accessed on 22.08.2020

$4 \mathrm{https}: / /$ www.delltechnologies.com/content/dam/delltechnologies/assets/perspectives/2030/pdf/SR1940_IFTFfor DellTechnologies_Human-Machine_070517_readerhigh-res.pdf (p. 16)

${ }^{5} \mathrm{https}: / /$ inaco.ro/wp-content/uploads/2018/09/Ghidul-meseriilor-viitorului-6-sep-2018.pdf (pg.13)

${ }^{6} \mathrm{https}: / /$ rum.29moons.com/3-ways-exponential-technologies-are-impacting-future-learning- 
In 2018, the first cars with "automatic driver" ${ }^{17}$, with "artificial intelligence driver" were put into operation. Now, in 2021, all major manufacturers of vehicles are fundamentally reconsidering their production strategy, more and more deciding to build "computers on wheels", "cars with artificial intelligence driver". More and more of the big companies (Tesla, Volkswagen, Audi, etc.) will produce only electric vehicles, and most of them will be (in the next 8-10 years) with "automatic driver".

Electric cars will become widespread around 2030, and soon will be only with automatic driver. These will radically change the lives of mankind "Computers on wheels" (i.e. "electric cars and with automatic driver") will lead to the disappearance of car repair services. Given the use of electric cars, it is easy to understand that gas stations will disappear. Also, over $95 \%$ of car insurance activities will disappear because car accidents will be reduced to the same extent (or even higher).

In many of the current professions, the number of jobs will be reduced by up to $90 \%$. A good example of this is with young lawyers in the US, who no longer have jobs. The supercomputer based on the concept of artificial intelligence called "Watson IBM" provides data, consultations and legal advice, in full legality, in a few seconds, with an accuracy of $90 \%$, compared to an accuracy of $70 \%$ when made by lawyers. Only erudite elites will remain.

Watson, also called Watson $\mathrm{IBM}^{8}$, is a computer system with artificial intelligence, capable of answering questions asked in natural language. "Watson IBM Artificial Intelligence Doctor" is a supercomputer based on the concept of artificial intelligence, which can be programmed to recognize and process voice commands, recognize visual stimuli and react to facial expressions. "Artificial Intelligence Doctor Watson" already helps doctors who diagnose cancer 4 times more accurately than human doctors. He develops plans, can learn, solve complex problems, imitating the human ability to make decisions. To replicate human qualities, Watson accesses 90 servers that store approximately 200 million pages of information (!!!) that they process in a very short time.

Elon Musk warned in early 2020 that humanity risks being overtaken by $\mathrm{AI}^{9}$ in the next five years ${ }^{10}$.

Industrial robots and co-robots or robots (collaborative robots created according to game theory) have AI, autonomous abilities of cognition, decision, learning and adaptation. They are equipped with sensors, technologies and intelligent systems that connect them to other ecosystems ${ }^{11}$.

$\mathrm{AI}$ is a smart digital system that learns on its own, develops its own search and learning systems, can even have its own language (without being understood by people), develops artificial neural networks on its own, can write its own programs,

\footnotetext{
7 Nicolae Grigorie Lăcriţa, Inteligența artificială produce schimbări epocale și rapide la nivelul întregii omeniri, www.juridice.ro 11.02.2021

${ }^{8} \mathrm{https}$ ///raportuldegarda.ro/articol/ibm-watson-supercomputer-tratamentul-cancer-cu-precizia-oncolgilor/

${ }^{9}$ Artificial Intelligence

${ }^{10}$ Daniel lonaşcu, Cyborgii tot mai aproape, Libertatea newspaper from September 2, 2020

${ }^{11}$ Carmen Silvia Paraschiv, Digitalizarea şi dreptul, in Dreptul nr. 9/2019, p. 121
} 
but the most more important is that he has decision-making power. Depending on the knowledge he has, he can decide the actions he does or does not do, being able to predict their result. In other words, AI no longer depends on a human command. Therefore, AI evolves on its own, by analyzing data, gradually expanding its neural networks, improving its performance. She learns at a much higher speed than a human, plans her way of learning and structuring data and especially decides for herself ${ }^{12}$.

An AI equipped with the right sensors would be superior to human intelligence and, in addition, AI has two nonhuman abilities that give it superiority: connectivity and updating, meaning we will have AI networks connected ${ }^{13}$.

AI can be billions of times smarter than humans. She can learn very quickly and can far exceed people's intelligence ${ }^{14}$.

Many times today AI chooses us: Netflix recommends movies; Google Maps or Waze choose the route to the destination; Google Books decides what we study. Authority shifts from people to algorithms.

Between 400 million and 800 million employees will be replaced by robots globally by 2030 , forced to find other jobs. Of these, up to 375 million people, roughly $14 \%$ of the world's workforce, will have to turn to completely different occupational categories. Those hardest hit will be employees in more developed economies, such as the US and Germany, where a third of the workforce will have to retrain by 2030 to find new jobs. The impact will be less in the poorest countries simply because they will not allow new technologies.

The rise in automation has so far been a negligible impact on the world's jobs, despite grim predictions of replacing workers. Even if advanced economies have lost industrial sector jobs in the past two decades, the expansion of the same sector in East Asian economies has offset the number of jobs lost in advanced economies, according to a World Bank report ${ }^{15}$.

For the European Union, the digital single market has been a priority since 2010, adopting numerous strategies and reports, and the European Commission adopted on

19.02.2020 a white paper ${ }^{16}$ on artificial intelligence which states that Europe's development will be based on the value created by data, and Artificial Intelligence is one of the main components of this development. Thus, we will find disruptive AIbased technologies in more and more fields and it will be available to anyone to use.

The European Commission is correcting "responsible" and human-controlled artificial intelligence by presenting the EU strategy for this strategic and sensitive

\footnotetext{
${ }^{12}$ Laura Georgescu, Inteligența artificială și impactul ei în societate, mai ales în ce privește locurile de muncă, Revista română de dreptul muncii, nr. 2/ 2018, p. 14-15

${ }^{13}$ Carmen Silvia Paraschiv, art. cit, p.124

${ }^{14}$ Laura Georgescu, Ce este și cum poate fi folosită inteligența artificială (I), Revista română de dreptul muncii, nr. 3/ 2018, p. 17

${ }^{15}$ Dan Top, El cambio tecnológico y el futuro del derecho laboral - Uso de robotes industriales, in Congreso Interuniversitario sobre el Futuro del Trabajo, Facultad de Ciencias del Trabajo, Universidad de Sevilla, 7-8 februarie 2019, vol. II, Ministerio de Trabajo y Economia Social, Sevilla, 2019, p. 130

${ }^{16}$ European Commission - White Paper On Artificial Intelligence - A European approach to excellence and trust, COM (2020), Brussels
} 
sector. that it did not take advantage of the first internet revolution, which led to the emergence of American giants in the field, such as Google and Facebook, or Chinese giants such as Tencent, the EU now wants to play a central role in defining rules and promoting its own companies. The EU document describes the risks inherent in using AI "to track and analyze people's daily habits", as well as the potential of state authorities to exploit technology for mass surveillance. The EU White Paper also suggests adopting different rules, depending on where and how an AI system is used. A high-risk system is one that is used in a critical sector, such as healthcare, transport or the police, and that has a critical use, such as legal changes or the decision on social security payments. The aim is to create a single European data market and ensure that artificial intelligence technologies take into account privacy concerns and ethical issues ${ }^{17}$.

The world of COVID-19 will need more and more automation to keep people safe, the pandemic robotics solutions are not limited to the medical field but could also assist customers in industries such as retail and air transportation. Although the technology is still in its infancy, the pandemic could accelerate a relationship between humans and robots. Hanson Robotics plans to launch a robot named Grace, which was designed specifically for the healthcare industry.

About $50 \%$ of currently employed workers will need new skills by 2025 to meet the needs of the Covid-19 labor market crisis. The pandemic has led to a 5-fold increase in the learning opportunities offered by employers for their own workers and a four-fold increase in the number of people looking for online learning opportunities on their own initiative.

These efforts need to be accelerated, coordinated and supported by states, all the more so as OECD studies show that employees whose jobs are at high risk of automation remain 30 percentage points less willing to participate in vocational training and retraining, compared to those who have jobs with a low risk of automation ${ }^{18}$.

In a study conducted by the European Center for the Development of Vocational Training (Cedefop) ${ }^{19}$, about $14 \%$ of jobs in the EU can be replaced by automation solutions. Their ranking is dominated by trades that involve a series of recurring duties and do not require exceptional skills. Here are mentioned trades in the area of utilities, construction, agriculture, production and retail. Of course, other areas are not entirely immune to the presence of such transformations. In some of these, such as education, digitization solutions and the use of artificial intelligence algorithms can be considered two key components for the development and preparation of future generations of pupils and students for future technological revolutions that will follow in the more or less distant future.

$17 \mathrm{https}$ ///www.economica.net/europa-si-a-prezentat-marea-strategie-pentru-inteligenta-artificiala-undesta-romania-la-investitii_180179.html

${ }^{18}$ Răzvan Diaconu, Temelia Bugetului și a PNRR: $50 \%$ din actualii lucrători vor avea nevoie de noi calificări până în 2025, www.avocat net.ro, 8 februarie 2021

${ }^{19}$ www.cedefop.europa.eu 
In this context, it is worth noting that this concept of automation is not entirely new. Robots, such as those used on production lines, have been used for decades. This is the time when technology has evolved enough to be able to successfully introduce automated solutions in other sectors and reduce final costs. According to studies conducted by the McKinsey Global Institute ${ }^{20}$, this type of acceleration of economic domains is driven by three main factors.

First of all, "machine learning algorithms" have made tremendous progress in recent years. This was mainly due to the increase in data volume and computing power, both at the individual device level and at the data center level. A very good example here is the fact that initially a video card from a computer was intended, especially, for games, but now it has become a stand-alone processing unit used successfully in various complex processes. Among the latter, along with the rendering of images and other related solutions, achievements and content consumption for domains in the range of virtual and / or augmented reality, it is worth mentioning their usefulness for "cryptocurrency mining". These individual graphics processor processing solutions are used even more successfully in running the algorithms used to process huge amounts of data.

Currently, due to technological developments at the industry level, there is an incredible flow of data and metadata that are constantly generated and that can be monetized using such algorithms specific to artificial intelligence solutions. From images and videos, to voice data, location and even patterns of use of technologies and online browsing habits, these are just some of the structured and unstructured data that can be used and processed for commercial purposes. To the latter, if we add the component of "Internet of Things", which has become a basic pillar in better understanding the habits and how various processes can be optimized, and how to create a true living ecosystem that to help significantly reduce the costs of processes, operational, production, maintenance, service improvement and more.

In this context, it is worth mentioning some of the smart city initiatives that are already implemented and functional worldwide. In Shenzhen, for example, traffic jams were reduced by $12 \%$ and the average speed of cars increased by $6 \%$ during peak hours. More importantly, the response time of emergency crews, for exceptional cases, has decreased by $40 \%$ due to improvements in road infrastructure and the permanent monitoring system ${ }^{21}$.

The job market is changing radically in the next decade. Automation through robots and artificial intelligence (AI) will influence more than a third of jobs in almost all European countries by 2030, and Romania is no exception. Some jobs will disappear, but new ones will emerge that we haven't thought about yet.

In Romania, the potential for job automation is about $50-60 \%$ of their total. This does not mean that they will disappear, but that they can be changed. A fully

\footnotetext{
${ }^{20}$ www.mckinsey.com

${ }^{21}$ Smile Media Furtuna perfectă care schimbă societatea de mâine: "roboții" care lucrează împreună cu oamenii și internetul care face posibilă conectarea tuturor sistemelor si echipamentelor, www.hotnews.ro, 21 aprilie 2021
} 
automated job is a job for which the technology is in a development stage that provides a viable substitute for it (for example, a car without a driver). Polarized automated jobs occur when patent technology has had some success, but these developments are expected to progress to polarization, with human employees needed where personal interaction has real value and robots being used where not.

For example, serving staff can be replaced with robots in some units, but is unlikely to replace waiters who offer experience in luxury restaurants. Employment will increase largely for occupations that require higher education and IT\&C knowledge. The jobs most affected by robotics and AI are jobs that involve lowcomplexity, standardized tasks that are repeated with high frequency. For example: production workers on assembly lines, drivers and operators of mobile units, workers in the mining industry and cleaning workers. The jobs that will be radically transformed will be those that have in their composition tasks of medium complexity,

but include complex social interactions ${ }^{22}$.

The technologies with the greatest development in the next 5 years, technologies that require new roles and skill sets, so that they will have a great impact on the labor market:

- Artificial Intelligence (in digital information, financial services, health services and transportation)

- Big data

- The Internet of Things

- Robotics (in the mining and metals industry)

- Encryption (public sector)

The average working time of cars and people will reach parity in 2025, studies show.

Algorithms and machines will focus primarily on information tasks, data processing and retrieval, administrative tasks and some aspects of manual labor.

Romania, the EU country with the lowest percentage of employees who participated in a professional training course. Romania, the country with the penultimate share of being on the last place in the European Union in terms of employee participation in education and training courses, according to Eurostate Eurostat. Only 1.6\% of Romanian employees attended vocational training courses in 2019.

The European Union average was almost 10 times higher than the Romanian average $-14.8 \%$ of European workers attended a course, training, etc. For comparison, in Sweden, the percentage was 37\%, and in Switzerland 39.4\%.

Looking at the macro level, technological evolution has revolutionized the traditional business model as a whole. Therefore, industries in all branches, cities, homes and homes have benefited from significant improvements due to new innovative technological solutions, which are based on robotic components and / or mechanisms based on artificial intelligence. Thus, artificial intelligence algorithms can now run extremely well both locally, dependent on computing power at the

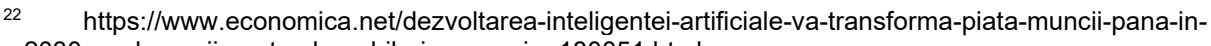
2030-ce-domenii-sunt-vulnerabile-in-romania_180051.html 
device level, but much more efficiently in a cloud-like ecosystem, where data from various equipment, systems can be analyzed and compared. for efficiency in operation and consumption. Cloud-connected solutions require a fast-paced Internet network to serve the most efficient flow of data and information, as evidenced by the need today to use revolutionary technologies such as Wi-Fi 6.0 and 5G.

The big picture for a faster and safer internet, with many more connections, looks like this: ,,a network based on artificial intelligence algorithms, which mimics the way the human brain itself manages millions of data / information in real time, "understands", "knows" and can make predictions about needs and network load"23.

If we are currently talking about network administrators who can fix any connection problems, especially in production areas such as the automotive or mining industries, in the future these problems should be foreseen and remedied automatically with human intervention. limited or close to zero. In an analysis by Liu Yunjie, an academician at the Chinese Academy of Engineering, we learn that the fundamental changes the Internet has undergone in its first four decades of existence require the development of new techniques and theories for the needs of future decades. The success of such a transformation related to the needs of the future consists both in eliminating as much as possible the shortcomings at the level of the present infrastructure, as well as in developing innovative devices and systems for the needs of the networks of the future.

According to him, by analyzing data at the network level and through the use of artificial intelligence technologies, today's computers can detect possible problems and security risks much faster and also can propose solutions to fix them in real time in more than $90 \%$ of cases that may occur. Thus, people, specialists, would focus on the remaining $10 \%$, which computers cannot solve and require human intervention.

To these data are added possible security issues. Large cybersecurity companies are already successfully using AI tools capable of identifying the most threats on their own. In an ideal scenario, we should be able to use artificial intelligence to identify these network-level security issues before they reach potential victims. In such an approach, Huawei claims that it has managed, through the use of artificial intelligence solutions, to identify $87 \%$ of threats at the network level.

Guilds or collaborative robots are typically intended for physical interaction with people in a common workspace. ${ }^{24}$

More and more industries seek ${ }^{25}$ to replace employees with robots, who can work continuously and whose work is not taxed by the state.

The automotive and metalworking industries are the largest markets for nobility, followed by electronics, plastic, food and pharmaceutical processing.

\footnotetext{
${ }^{23}$ Smile Media Furtuna perfectă care schimbă societatea de mâine: "robotiii" care lucrează împreună cu oamenii și internetul care face posibilă conectarea tuturor sistemelor si echipamentelor, art.cit

24 James É. Colgate, Michael A. Peshkin, Witaya Wannasuphoprasit, Cobots: Robots for Collaboration with Human Operators, Proceedings of the International Mechanical Engineering Congress and Exhibition, Atlanta, GA, DSC-Vol. 58, Nov. 17-22, 1996, pp. 433-439

${ }^{25}$ http: // www. epochtimes-romania.com
} 
These robots work alongside laborers and are flexible, easy to program, secure and inexpensive. Romania had in 2016, according to the International Federation of Robotics $^{26}, 11$ industrial robots per 10,000 industrial workers.

There is no doubt that the world of collaborative robots is on the rise, so labour law will have to distinguish between non-human workers (dwarfs, industrial robots, etc.) and human workers, regulations in the field will evolve, meaning that provisions will be needed which will determine, at a minimum, what the relationship between the two categories of workers will be according to the specificity of the activity, as well as other aspects.

Social protection, if jobs are reduced due to re-technology and introduction of IA, could be offset by state-owned companies by introducing indemnities, permanent social benefits, to maintain a decent living standard for humanity. Thus, man should no longer be concerned about subsistence needs - shelter, hygiene, food, etc., but develop his creative part, educate and teach new generations in this regard, thus finding time for new inventions, for us solutions, new experiments and discoveries. ${ }^{27}$

It remains to be seen how collective bargaining will be the future of industrial robots, can unions or employees' representatives force the employer to use only a limited number of industrial robots? Will employers be able to replace the work of human workers with industrial robots in case of strikes or the absence, for other objective reasons, of workers?

These questions, as well as many others, are awaiting a firm response from the legislator, the only one able to ensure a reasonable balance ${ }^{28}$.

Six years ago, the first humanoid robot produced by Hanson Robotics (Hong Kong) was created. Sophia, modeled on actress Audrey Hepburn, since April 19, 2015.

The programmers built it so that it has as many of the features of the human race as possible: it has preferences and feelings, it is able to have conversations and can imitate over 50 facial expressions and it is even programmed to have a high sense of humor. She understands facial expressions caused by different emotions and can imitate them in turn ${ }^{29}$.

In 2017, Sophia received the citizenship of Saudi Arabia, being the first robot in the world to receive this honor, at the same time Sophia is the first robot to hold a credit card, being a client of Unicredit Bank, starting in 2018.

Such a new category of legal subjects that might have rights and obligations would be added to traditional ones, legal entities and individuals who might be present at a certain moment in the labour market.

\footnotetext{
${ }^{26}$ World Robotics Report 2016, www.ttonline.ro

${ }^{27}$ Idem, p. 29

${ }^{28}$ Dan Top, Artificial Intelligence and the future of Labor Law, Acta Universitatis Sapientiae Legal Studies,

Vol. 8, No. 2, 2019, p.247

${ }^{29}$ Claudia Stanciu, Oamenii și roboții pot conviețui? Povestea Sophiei, www.juridice.ro, 19 aprilie 2021
} 
It was said ${ }^{30}$ that "the humanoid robot Sophia, the first robot who acquired citizenship (Saudi Arabia decided in October 2017), is considered a thing, and not a person, and must be dismantled and brought into luggage to travel by airplane, for example, and granting human rights to humanoid robots, even if they are much reduced at an early stage, would be a major error in the thinking of any legislator. It will be just a step towards eliminating people ..."

This robot is legally recognized as his own personality ${ }^{31}$, but starting from the idea that a humanoid robot is a man-made thing, it does not allow it to be regarded as a legal entity, not even on the basis of a legal fiction, as it is made in the nineteenth century with legal entities, entities made up of individuals and that can not exist independently of individuals.

Even if it can be argued that humanoid robots can not function without the software of the physical person that creates it, there is still the fear that they will be able to "update" to the point that they will no longer need software and thus recur to the elimination or dominance of human intelligence.

Creating a register for intelligent autonomous robots, as proposed by the European Commission, would only solve the patrimonial responsibility of the intelligent robot, which would obviously come to the owner, and could not be a document for the recognition of an "electronic person" a distinct subject ${ }^{32}$.

Some examples of the replacement of the human workforce at international level are relevant. A New York Hotel, Yotel, which is fully automated and assisted by IA. ${ }^{33}$ It has check-in and check-out automatically, adjustable and comfortable, motorized bedding that folds to benefit in the extra space room, a robot permanently prepared to help luggage customers, etc.

China announced in November 2017 the planning of the opening of police stations without human staff, fully automated and assisted by IA. ${ }^{34}$

Another example of the IA that took the place of people is Amelia, who works at the UK Local Council. Amelia is scheduled for customer service and administration; she is able to analyze natural language, understand the context, apply logic, learn, solve problems and even feel emotions. ${ }^{35}$

The goal of Hanson Robotics is to improve the quality of life, and one day robots will be imperceptible to humans. Motivated by the crisis caused by the Sars-Cov- 2 virus, they will launch four versions of robots to be used in hospitals, shops and airports. The company also created a robot specialized in the medical field, called Grace.

Also, in the context of the coronavirus pandemic, another company specializing in this industry in Japan, SoftBank Robotics, created the Pepper robot. He has the

\footnotetext{
${ }^{30}$ Dobozi, Partner, Tudor Colţan, Civil Rights for Humanoid Robots, www. HotNews.ro

31 Laura Georgescu, art. cit., p. 18

32 Dan Top, Artificial Intelligence and the future of Labor Law, art. cit., p.249

$33 \mathrm{https}: / /$ www.youtube.com/watch?v=U81M7SjZjWY, https://www.tripadvisor.com/LocationPhotoDirectLinkg60763-d2079052-i75110632-YOTEL_New_York-New_York_City_New_York.html

$34 \mathrm{https}$ ://futurism.com/chinas-ai-police-station-humans/ and $\overline{\mathrm{h}} \mathrm{ttps}$ ://thenextweb.com/artificial-intelligence/ 2017/11/09/china-is-building-a-police-station-powered-by-ai-nothumans /

${ }^{35} \mathrm{https}$ //www.mirror.co.uk/news/uk-news/robot-amelia-who-can-sense-8215188
} 
ability to detect people who do not wear a mask, a goal appropriate to the times in which we live.

The Estonian Ministry of Justice has implemented a computer program ${ }^{36}$ to replace the judge. These are files that can be easily standardized, respectively those files set up as a result of claims in claims of low value, being about amounts less than 7,000 euros.

The program for the judiciary requires the applicant to complete the application form to which he attaches scans of probation annexes - roughly in the same way as the European Court of Human Rights website - but does not stop there, but rules and the solution. Which can be an administrative one, prior, if a document is missing or, if the lack is not fulfilled or is fulfilled and the procedure can be continued, there will be a solution on the merits of the case.

There is an appeal, but it is to a human judge, this time, and only for issues related to system errors. That is, the judge relies on what a computer scientist tells him. If there is no system error, there are no grounds for appeal or recourse.

The ambitious Estonian project aims to replace at least 100 employees in the judiciary. Its improvement will be carried out along the way, depending on the feedback from the beneficiaries. The future will tell us if this beginning will lead to SF courtrooms, with humanoid robots, establishing the children's home or sharing punishments.

\section{Conclusion:}

Will the last industrial revolution (Industry 4.0 ) be the last in the history of humanity? Robots are increasingly present in our lives and we must prepare for the time when they will take over some of our jobs.

The Industrial Revolution 4.0 is a natural step in the evolution of humanity, a new challenge for human civilization, which should not restrain itself from using robots in economic activity, they will never be able to fully replace human intelligence, artificial intelligence even superior to human will always be dependent on the latter who will have the lead role.

Replacing human labour with robots is no longer just a discussion, it's a reality, it's not just a SF issue, it's something society should think and anticipate by updating legislation and social protection in a way or else of the people.

The present allows us to imagine a near future in which industrial robots and autonomous machines find their place in our activities and lives.

${ }^{36}$ Veronica Dobozi, Vor fi judecătorii înlocuiți de roboți? www.hotnews.ro, 24 octombrie 2019 